\title{
Spatial and Seasonal Changes in Total and Phosphate Phosphorus Concentrations in the Water of National Nature Reserve Čičov Oxbow in the Southwestern Part of the Slovak Republic
}

\author{
Mária Babošová*, Jana Ivanič Porhajašová, Terézia Čeryová \\ Department of Environmentalism and Biology, Faculty of Agrobiology and Food Resources, \\ Slovak University of Agriculture in Nitra, Tr. A. Hlinku 2, 94976 Nitra, Slovakia
}

Received: 22 September 2020

Accepted: 16 November 2020

\begin{abstract}
In the years 2013 and 2014 the waters of the National Nature Reserve Čičov oxbow lake in the southwestern part of the Slovak Republic were analyzed for total and phosphate phosphorus concentrations. Collections of samples were inspected regularly at monthly intervals, always in the middle of the month. The results were compared with the limit values set out by the Government Regulation No. 269/2010 Coll. The average concentration of total phosphorus for individual months during both monitored years was $0.19 \mathrm{mg} \cdot \mathrm{dm}^{-3}$ with the maximum average concentration in the month of June $\left(0.26 \mathrm{mg} \cdot \mathrm{dm}^{-3}\right)$ and the minimum in the months of August and September $\left(0.15 \mathrm{mg} \cdot \mathrm{dm}^{-3}\right)$. Its average concentrations at individual sampling sites were relatively balanced and varied from 0.16 (at a side arm of the National Nature Reserve) to $0.23 \mathrm{mg} \cdot \mathrm{dm}^{-3}$ (at the river mouth of the Cilizian stream into a dead arm). The average concentration of phosphate phosphorus for individual months during both monitored years was $0.08 \mathrm{mg} . \mathrm{dm}^{-3}$. Depending on the time of sample collection, its average concentrations ranged from 0.05 (November) to $0.12 \mathrm{mg} \cdot \mathrm{dm}^{-3}$ (August). Depending on the sampling site, the average phosphate phosphorus concentrations varied from 0.07 to $0.10 \mathrm{mg} \cdot \mathrm{dm}^{-3}$. The data for the year, the month, and the sampling site showed a statistically high significant effect on total phosphorus, and a statistically significant effect for phosphate phosphorus was recorded from data for the month.
\end{abstract}

Keywords: phosphate phosphorus, total phosphorus, water quality, surface water, Slovak Republic

*e-mail: Maria.Babosova@uniag.sk 


\section{Introduction}

Low concentrations of phosphorus can be found in undisturbed water sources mainly due to weathering, which is mostly a slow process, therefore it is relatively a rare element [1]. It is an important nutrient, which stimulates the growth of aquatic organisms in water bodies. In natural, uncontaminated waters, it occurs as an organically bound phosphate, phosphates or as an orthophosphate [2]. Phosphorus is present in surface waters naturally (as a result of mineralization processes of vegetable and animal residues) or due to anthropogenic pollution: diffused sources from agriculture, the untreated or insufficiently treated municipal waters and the use of polyphosphate detergents [3, 4]. The small quantity of phosphorus present in natural waters does not promote the growth of plants, but in excessive quantities phosphorus has a fertilizing effect that affects both the ecosystem and the water quality as a whole $[5,6]$. However, a rise in the concentration of phosphorus results in the proliferation of algae, which leads to the eutrophication of the water body. The primary cause of eutrophication is the high concentrations of nutrients in the aquatic environment [7]. Eutrophication is a complex process that occurs in natural waters when certain types of algae grow excessively and become a threat to human health [8]. Anthropogenic phosphorus (P) and nitrogen (N) pollution is currently the main drivers of eutrophication, with excessive inputs of these two nutrients into the freshwater water bodies being considered as one of the most urgent environmental issues that human societies face [9-11].

\section{Materials and Methods}

\section{Study Area and Sampling Sites}

National Nature Reserve Čičov oxbow lake $\left(47^{\circ} 46^{\prime} \mathrm{N}-17^{\circ} 43^{\prime} \mathrm{E}\right)$ is a left-side oxbow of the Danube river, which is separated from the main stream by a dam. Located on the Danubian Plain in the most wooded part of the protected landscape area, $30 \mathrm{~km}$ from Komárno in the direction to Bratislava. It is located in the cadastral area of Čičov and Kl'účovec at an altitude of $110 \mathrm{~m}$ above sea level, and it belongs to the river-basin of Danube. The National Nature Reserve was declared in the year 1964 on an area of 79.8715 ha, the water area is 79.87 ha, the protective zone area is 55.25 ha. Čičov oxbow lake is considered to be the largest oxbow lake in Slovakia. The average water depth is about $3 \mathrm{~m}$, the maximum measured depth was $7.5 \mathrm{~m}$. Bank is divided by small peninsulas and bays. It is an important habitat for aquatic and wetland communities, which are characteristic for meadow forests along the Danube River with 24 species of fish, over 100 species of birds and several other rare species of animals and plants [12]. The area is particularly influenced by the flow of Danube, from which oxbow lake water is fed by a subsurface seepage. It is dependent on the water level of the surrounding area, waterlogging, and floods at high states. From mid-summer the groundwater is declining because evaporation dominates over precipitation. The Rye island opens into the oxbow lake channel Vrbina - Medved'ov and Čilizian stream. It is an area of rainsnow runoff, with the highest accumulation of water in December through January, with high water levels in February through April. Geological structure consists mostly of Neogene clays - pannonian sediments of the lake, covered by quaternary Holocene alluvial sediments of gravel, sand, loess and flood waters. The basic quaternary elements are: fluvial - wetland sediments with organic additives and fluvial - alluvial sediments in the lowlands. In terms of soil conditions the western part of the area is dominated by clayey soil types and the eastern part it is dominated by clay-loam soil. The main soil types are: black soils carbonate, local peat soils on the carbonate alluvial sediments, and alluvial gley soils on the carbonate and non-carbonate sediments, mollicgley, mollicfluvisols and gley on the carbonate and non-carbonate alluvial sediments. Hydrogeological basis of the area consists from quaternary sands and alluvial gravels. National Nature Reserve Čičov oxbow lake is situated in the dry to moderately dry areas with an average annual temperature of $9.9^{\circ} \mathrm{C}$. The coldest month is January, with the average monthly temperature of $-2.1^{\circ} \mathrm{C}$ and the hottest month is July, with the average monthly temperature of $20.5^{\circ} \mathrm{C}$. Average annual rainfall is $550-600 \mathrm{~mm}$, the most precipitation falls during the months of May, June and July (average monthly rainfall of $59.3 \mathrm{~mm}$ ). The area is located in one of the windiest parts of Slovakia. The maximum speed of the wind and the windiest days occur in winter and spring. The predominant wind direction is NW [13].

\section{Collecting and Processing of Samples}

Samples were collected regularly at monthly intervals, always roughly in the middle of a month during years 2013 and 2014. Sampling sites were determined in order to assess the impact of natural and the anthropogenic sources of surface water quality. Specifically, we identified eight sampling sites (Fig. 1):

1. Sampling site: $47^{\circ} 46^{\prime} 7.17^{\prime \prime}$ north latitude and $17^{\circ} 43^{\prime} 7.56^{\prime \prime}$ east longitude, $110 \mathrm{~m}$ above sea level, located about $150 \mathrm{~m}$ from the mouth of the Čilizian stream into the reserve. The depth is $0.31 \mathrm{~m}$.

2. Sampling site: $47^{\circ} 46^{\prime} 6.51^{\prime \prime}$ north latitude and $17^{\circ} 43^{\prime} 7.81^{\prime \prime}$ east longitude, $104 \mathrm{~m}$ above sea level, is located $20 \mathrm{~m}$ near the mouth of Čilizian stream. The depth is $0.37 \mathrm{~m}$.

3. Sampling site: $47^{\circ} 46^{\prime} 5.88^{\prime \prime}$ north latitude and $17^{\circ} 44^{\prime} 0.40^{\prime \prime}$ east longitude, $107 \mathrm{~m}$ above sea level, located in the northeastern part of the National Nature Reserve. The depth is $0.43 \mathrm{~m}$.

4. Sampling site: 47 $46^{\prime} 4.04^{\prime \prime}$ north latitude and $17^{\circ} 44^{\prime} 1.87^{\prime \prime}$ east longitude, $111 \mathrm{~m}$ above sea level, 
located in the northeastern part, with an depth of $0.43 \mathrm{~m}$.

5. Sampling site: $47^{\circ} 46^{\prime} 2.09^{\prime \prime}$ north latitude and $17^{\circ} 44^{\prime} 0.32^{\prime \prime}$ east longitude, $111 \mathrm{~m}$ above sea level, the depth is $0.50 \mathrm{~m}$.

6. Sampling site: $47^{\circ} 46^{\prime} 0.02^{\prime \prime}$ north latitude and $17^{\circ} 43^{\prime} 8.26^{\prime \prime}$ east longitude, $111 \mathrm{~m}$ above sea level, is located on the first side distributary. The depth is $0.37 \mathrm{~m}$.

7. Sampling site: $47^{\circ} 46^{\prime} 2.23^{\prime \prime}$ north latitude and $17^{\circ} 43^{\prime} 4.45^{\prime \prime}$ east longitude, $117 \mathrm{~m}$ above sea level, located on the second side distributary of reservation, the depth $0.39 \mathrm{~m}$.

8. Sampling site: $47^{\circ} 46^{\prime} 3.77^{\prime \prime}$ north latitude and $17^{\circ} 43^{\prime} 5.91^{\prime \prime}$ east longitude, $117 \mathrm{~m}$ above sea level, located in the second side distributary of reservation, the depth $0.39 \mathrm{~m}$.

Concentrations of the phosphates in the water samples taken were determined by colorimetry with stannous chloride, and of the total phosphorus with added ammonium molybdate. Values of phosphate phosphorus and total phosphorus were expressed in mg.dm ${ }^{-3}$.

Temperature water and chlorophyll-a were not monitored in the area of interest.

To evaluate individual indicators of the quality of surface water in the sampling sites we used the values of the $90^{\text {th }}$ percentile (P90), which was calculated from the measured values and then compared with their matching set of limit values referred in the Regulation

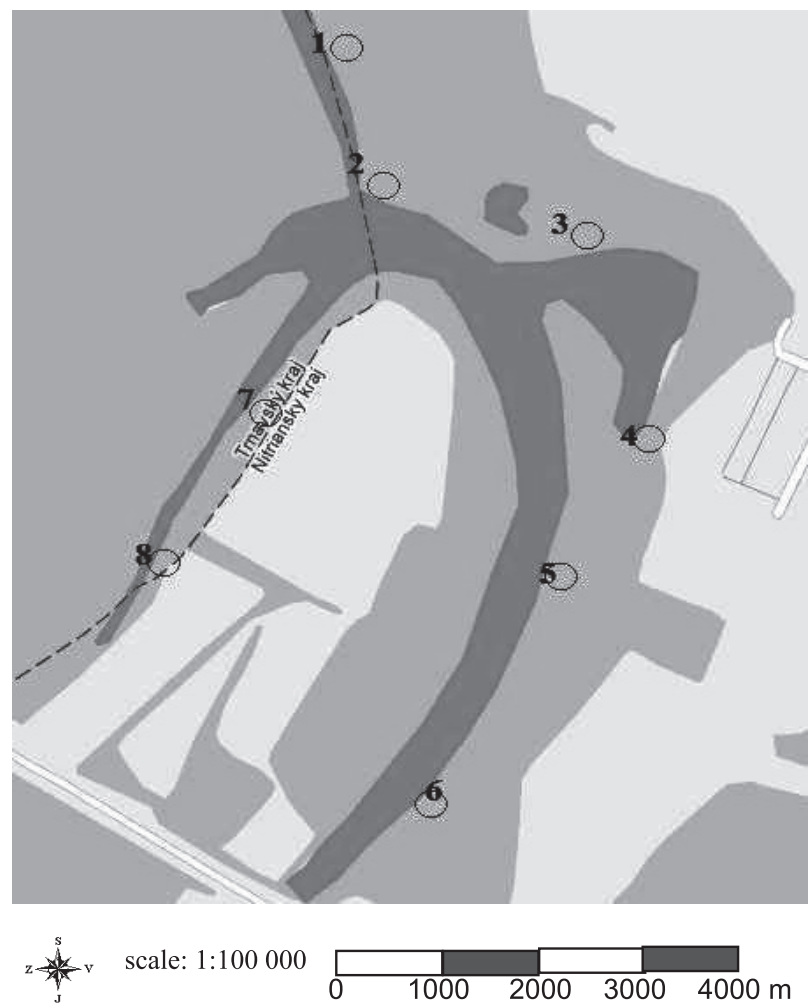

Fig. 1. National Nature Reserve Čičov oxbow lake. Legend: -------- boundary between Trnava and Nitra regions

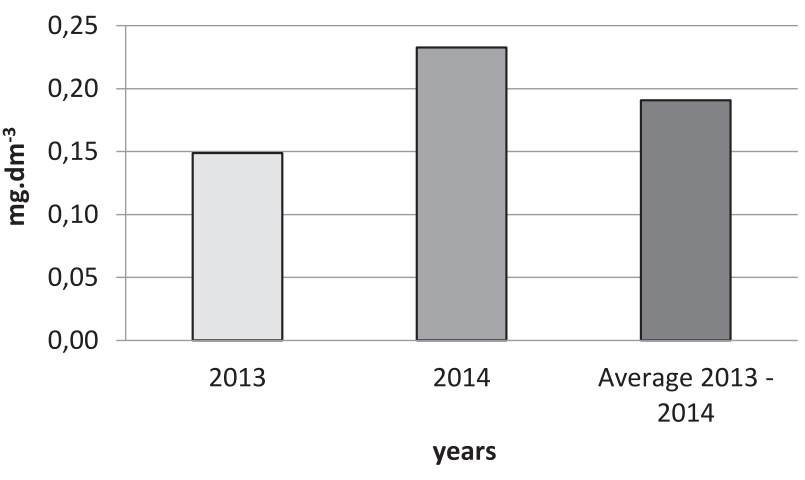

Fig. 2. Average concentrations of total phosphorus in the years 2013-2014.

of the Government of the Slovak Republic No. 269/2010 Coll [14]. The results were processed by mathematicalstatistical methods (using Statgraphics 5.0 plus).

\section{Results}

The average concentration of total phosphorus levels in the water of National Nature Reserve Čičov oxbow lake during the observed period ranged from 0.23 (year 2014) to $0.15 \mathrm{mg} \cdot \mathrm{dm}^{-3}$ (year 2013), and for the whole monitored period the average concentration was 0.19 mg.dm ${ }^{-3}$ (Fig. 2).

The maximum average concentration total phosphorus was recorded in June $2013\left(0.32 \mathrm{mg} . \mathrm{dm}^{-3}\right)$, at the same month when the highest average concentration for the whole monitored period $\left(0.26 \mathrm{mg} . \mathrm{dm}^{-3}\right)$ was also measured. We assume that the increase in the average concentration was caused by an intensive decomposition of organic matter found in the bottom sediments. From June, the average concentrations gradually decreased until August and September, when the minimum average concentration $\left(0.15 \mathrm{mg} \cdot \mathrm{dm}^{-3}\right)$ was recorded (Fig. 3).

Dynamics of the average concentrations of total phosphorus depending on the sampling site is shown

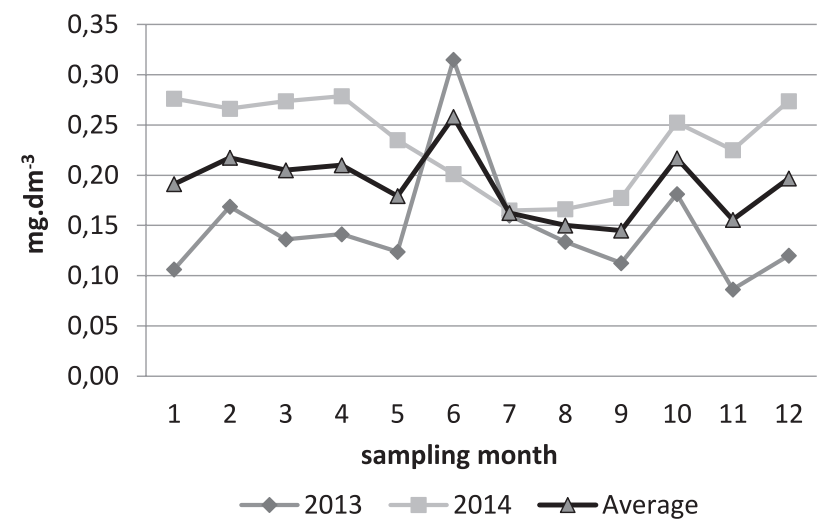

Fig. 3. Average concentrations of total phosphorus depending on the time of sampling. 


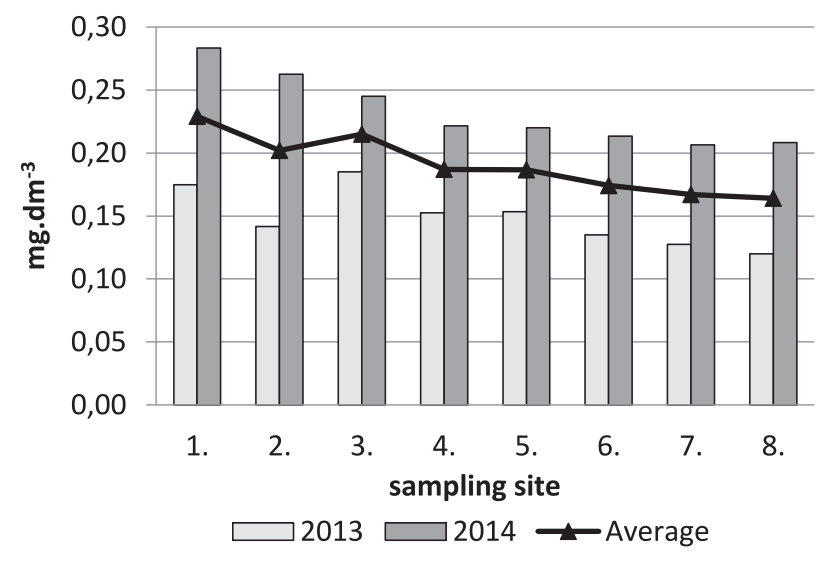

Fig. 4. Average concentrations of total phosphorus depending on the sampling site.

in Fig. 4. It can be stated that the average concentrations at individual sampling sites were relatively balanced and varied from 0.16 (sampling site no. 8 - in the second side arm of the National Nature Reserve) up to $0.23 \mathrm{mg} \cdot \mathrm{dm}^{-3}$ (sampling site no. 1 - at the mouth of the Čilizian stream into the oxbow lake).

The analysis of variance shows (Table 1), that the year, the month and the site of sampling had a statistically high significant effect on the total phosphorus. The interaction between the year and the month was highly significant, and the interaction between the month and the sampling site was statistically significant. The interaction between the year and the sampling site was inconclusive (Statgraphics 5.0 plus).

According to the Regulation of the Government of the Slovak Republic No. 269/2010 Coll the limit value of the total phosphorus is $0,40 \mathrm{mg}^{-\mathrm{dm}^{-3}}$. Calculated

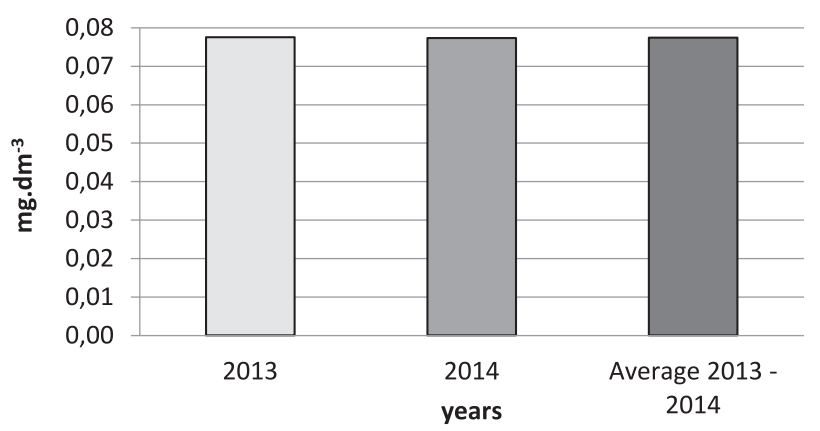

Fig. 5. Average concentrations of phosphate phosphorus in the years 2013-2014.

characteristic values of the $90^{\text {th }}$ percentile (P90) of total phosphorus varied from 1.22 (sampling site no. 1) to $0.25 \mathrm{mg} \cdot \mathrm{dm}^{-3}$ (sampling site no. 7). Based on the calculated values of the $90^{\text {th }}$ percentile (P90) of this indicator, we found that the calculated characteristic values exceeding the recommended value at sampling sites no. 1 and 2 (Table 2).

The average concentrations of phosphate phosphorus during the years 2013 - 2014 were balanced and the average concentration for the whole observed period represented 0.08 mg.dm ${ }^{-3}$ (Fig. 5).

Depending on the time of sample collection, higher average concentrations of phosphate phosphorus were detected in the summer. The maximum average concentration for the entire monitored period was recorded in August $\left(0.12 \mathrm{mg} \cdot \mathrm{dm}^{-3}\right)$. During this month in 2014, the highest average concentration was also recorded $\left(0.14 \mathrm{mg} \cdot \mathrm{dm}^{-3}\right)$. The lowest average concentrations were in the winter, with the minimum average recorded value for the entire observed period

Table 1. Analysis of variance for concentrations of total phospohorus.

\begin{tabular}{|c|c|c|c|c|c|}
\hline Effect & The sum of squares & Degrees of freedom & Mean square & F & P \\
\hline Year & 0.338312 & 1 & 0.338312 & 100.840 & 0.000000 \\
\hline Month & 0.199988 & 11 & 0.018181 & 5.419 & 0.000003 \\
\hline Sampling site & 0.091860 & 7 & 0.013123 & 3.911 & 0.001083 \\
\hline Year*Month & 0.280697 & 11 & 0.0025518 & 7.606 & 0.000000 \\
\hline Year*Sampling site & 0.019085 & 7 & 0.002726 & 0.813 & 0.579549 \\
\hline Month*Sampling site & 0.377462 & 77 & 0.004902 & 1.461 & 0.049787 \\
\hline Error & 0.254976 & 76 & 0.003355 & & \\
\hline
\end{tabular}

$\mathrm{F}$ - value, $\mathrm{P}$ - value

Table 2. The calculated characteristic values of the $90^{\text {th }}$ percentile for total phosphorus.

\begin{tabular}{|c|c|c|c|c|c|c|c|c|}
\hline \multirow{2}{*}{ Calculated characteristic value } & \multicolumn{9}{|c|}{ Sampling sites } \\
\cline { 2 - 10 } & 1. & 2. & 3. & 4. & 5. & 6. & 7. & 8. \\
\hline Total phosphorus & 1.22 & 1.18 & 0.37 & 0.28 & 0.28 & 0.26 & 0.25 & 0.26 \\
\hline
\end{tabular}




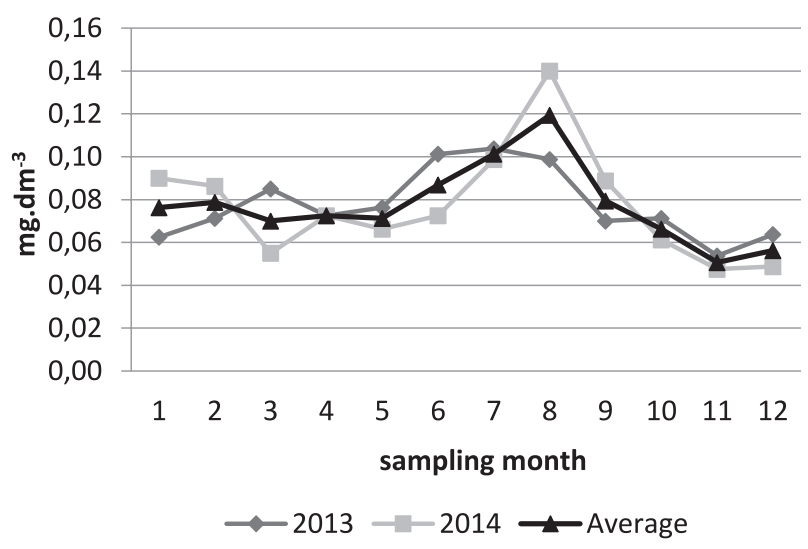

Fig. 6. Average concentrations of phosphate phosphorus depending on the time of sampling.

in November $\left(0.05 \mathrm{mg} \cdot \mathrm{dm}^{-3}\right)$. Lower concentrations during this period were probably caused by unsuitable temperature conditions for the decomposition of substances containing the organic forms of phosphorus (Fig. 6).

Depending on the sampling site, the average concentrations of phosphate phosphorus in the waters of the Čičovské oxbow lake National Nature Reserve were relatively balanced throughout the observed period (Fig. 7). The minimum average concentration (0.07 mg.dm $\left.{ }^{-3}\right)$ was recorded at sampling sites no. 2 (near the mouth of the Čilizian stream into the National Nature Reserve), no. 3 (in the north-eastern part of the reservation) and no. 5, located in the first side arm. The maximum average concentration $\left(0.10 \mathrm{mg} \cdot \mathrm{dm}^{-3}\right)$ was detected at sampling site no. 4, which was located in the northeastern part of the reservation. In 2014, this sampling site had the highest average concentration $\left(0.12 \mathrm{mg} . \mathrm{dm}^{-3}\right)$.

Based on the analysis of variance of phosphate phosphorus, the effect for the month was statistically significant. The effects for the year and the sampling site were statistically inconclusive. The interactions between the year, the month and the sampling site, as well as the interaction between the month and

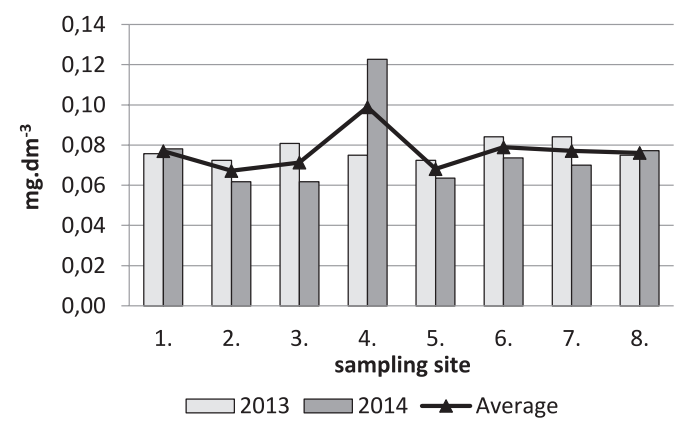

Fig. 7. Average concentrations of phosphate phosphorus depending on the sampling site.

the sampling site were also inconclusive (Table 3) (Statgraphics 5.0 plus).

The recommended limit value for phosphate phosphorus is not listed in the Regulation of the Government of the Slovak Republic No. 269/2010 Coll.

\section{Discussion}

Phosphorus is present in extremely low concentrations in the surface waters. It can be stated that sources of the eutrophic nutrients phosphorus (P) and nitrogen $(\mathrm{N})$ in the waters of the Čičov oxbow lake are external, they come from the waters that flow into the oxbow, but also internal - contained in the water and the sediments of the oxbow lake itself. Gradually, over a long period of natural disturbance regime, 'reserves' of these nutrients built up, and are accumulated in the sediments [15].

Concentrations of phosphorus compounds in the surface waters have variable characteristics. In relatively unpolluted waters, the concentration of total phosphorus is less than $0.025 \mathrm{mg} . \mathrm{dm}^{-3}$. Concentrations above $0.050 \mathrm{mg}^{-\mathrm{dm}^{-3}}$ in surface waters are generally considered to be the result of human activities. Concentrations of soluble form of phosphorus above $0.100 \mathrm{mg} \cdot \mathrm{dm}^{-3}$ lead to increased development of

Table 3. Analysis of variance for concentrations of phosphate phosphorus.

\begin{tabular}{|c|c|c|c|c|c|}
\hline Effect & The sum of squares & Degrees of freedom & Mean square & F & P \\
\hline Year & 0.000002 & 1 & 0.000002 & 0.0008 & 0.977572 \\
\hline Month & 0.061256 & 11 & 0.005569 & 2.0992 & 0.030251 \\
\hline Sampling site & 0.013863 & 7 & 0.001980 & 0.7466 & 0.633406 \\
\hline Year*Month & 0.021551 & 11 & 0.001959 & 0.7385 & 0.698415 \\
\hline Year*Sampling site & 0.015917 & 7 & 0.002274 & 0.8572 & 0.544179 \\
\hline Month*Sampling site & 0.170261 & 77 & 0.002211 & 0.8335 & 0.786331 \\
\hline Error & 0.201610 & 76 & 0.002653 & & \\
\hline
\end{tabular}

$\mathrm{F}$ - value, $\mathrm{P}$ - value 
algae and aquatic plants, which are secondarily the cause of organic pollution of surface waters [3]. In natural waters, phosphorus occurs in the form of inorganic orthophosphates $\left(\mathrm{PO}_{4}^{3-}\right)$, polyphosphates and organically bound phosphorus. Higher concentrations cause water eutrophication. It enters the waters in the form of orthophosphates and polyphosphates, most often from fertilizers, detergents, chemicals and wastewater. Organically bound phosphorus comes from the decomposition products of fauna and flora, animal waste and chemical preparations used in agriculture [16].

Depending on the season, the lowest average concentrations of phosphorus in water occur in the summer [17], when phosphorus is particularly important for growth of green organisms. Therefore, its concentration in the water during this period is lower, as intensive photosynthetic assimilation takes place [18, 19]. Higher concentrations in the summer come mainly from the decomposed de-sedimented biomass and not from long-lived sediment [20], or it can be leached from the soil into the water during heavy rainfall [21].

Based on the obtained results, it can be stated that higher average concentration of total phosphorus (0.68 mg.dm $\left.{ }^{-3}\right)$ and phosphates $\left(0.203 \mathrm{mg} \cdot \mathrm{dm}^{-3}\right)$ was found under the forest ecosystem of the Čaradický stream in the southwestern part of the Slovak Republic [22]. This concedes with the statement that phosphorus tends to be a minority element in natural waters. Phosphorus-containing mineral deposits have predominantly low solubility, so many surface waters have a very low phosphorus content. The content of soluble forms is in the range of $0.01-0.1 \mathrm{mg} \cdot \mathrm{dm}^{-3}$ and rarely exceeds $0.2 \mathrm{mg} . \mathrm{dm}^{-3}$.

Higher average concentrations of phosphate phosphorus were also found in the wetland waters of the Paris marshes in the open water $\left(0.25 \mathrm{mg}^{-\mathrm{dm}^{-3}}\right)$ and in the marginal part of the wetland $\left(1.37 \mathrm{mg}^{-\mathrm{dm}^{-3}}\right)$ [23], as well as in the river Trzemna $\left(0.38 \mathrm{mg} \cdot \mathrm{dm}^{-3}\right)$ [24]. The average concentration of phosphate phosphorus in the Winyah Bay wetland in the years 2010-2011 varied in the range of $0.01-0.08 \mathrm{mg} . \mathrm{dm}^{-3}$ [25].

\section{Conclusion}

In the Čičov oxbow lake National Nature Reserve, in the years 2013 - 2014, we evaluated the total concentrations of phosphorus colorimetrically using ammonium molybdate, and the phosphate concentrations colorimetrically using stannous chloride. The average concentration of total phosphorus for the whole monitored period was $0.19 \mathrm{mg} \cdot \mathrm{dm}^{-3}$, with the highest average concentration in June $\left(0.26 \mathrm{mg} \cdot \mathrm{dm}^{-3}\right)$. We assume that the increase in concentration was caused by an intensive decomposition of organic biomass accumulated in sediments. The minimum average concentration was determined in the months of August and September $\left(0.15 \mathrm{mg} \cdot \mathrm{dm}^{-3}\right)$. The average concentration of phosphate phosphorus for the whole monitored period was $0.08 \mathrm{mg} \cdot \mathrm{dm}^{-3}$. Depending on the time of sample collection, the average concentrations ranged from 0.05 to $0.12 \mathrm{mg} \cdot \mathrm{dm}^{-3}$. Depending on the sampling site, the average concentrations were relatively balanced and varied from 0.07 to 0.10 $\mathrm{mg} \cdot \mathrm{dm}^{-3}$. The year, the month and the sampling site showed a highly significant effect on total phosphorus, and the month had a statistically significant effect on phosphate phosphorus. The obtained water quality results can contribute to improvement of the quality of the reserve environment as an important habitat and nesting place for many species of birds. As most bird species depend on wetland habitats, they can be directly or indirectly affected by the degradation and quality of wetlands. At the same time, wetlands themselves can significantly affect the movement and quality of surface and groundwater.

\section{Acknowledgement}

This research was supported by the grant project VEGA 1/0604/20 „Environmental Assessment of Specific Biotopes of Danubian Lowland".

\section{Conflict of Interest}

The authors declare no conflicts of interest.

\section{References}

1. MOSS B. Cogs in the endless machine: lakes, climate change and nutrient cycles: a review. Science of the Total Environment, 434, 130, 2012.

2. VYSTAVNA Y., HEJZLAR J., KOPÁČEK J. Long-term trends of phosphorus concentrations in an artificial lake: Socio-economic and climate drivers. PLoS ONE, 12 (10), e0186917, 2017.

3. CHIN A.D. Water - quality engineering in natural systems. Fate and transport processes in the water environment. 2 ed. Hoboken: John Wiley and Sons, Inc., Hoboken, New Jersey, 472, 2012.

4. POSTOLACHI L., RUSU V., LUPASCU T. Managing phosphorus loads to water bodies. The case of the Hydrographical Basin of the Prut River. Managing Nitrogen and Phosphorus Loads to Water Bodies: Characterisation and Solutions, 44, 2014.

5. ZHANG W.Q, SHAN B.Q, ZHANG H., TANG W.Z. Characteristics of phosphorus compounds and their effects in sediments of an eutrophic Chaohu Lake, China. CleanSoil, Air, Water, 43 (4), 544, 2015.

6. ZHANG W., JIN X., ZHU X., SHAN B. Characteristics and Distribution of Phosphorus in Surface Sediments of Limnetic Ecosystem in Eastern China. PLoS ONE, 11 (6), e0156488, 2016.

7. TURAN Z. Determination and management of sensitive areas on the basis of watershed in Turkey. Managing Nitrogen and Phosphorus Loads to Water Bodies: Characterisation and Solutions, 63, 2014. 
8. JAMES E., ELEMA B.A. Phosphorus cycle: a broken biogeochemical cycle. Nature, 478 (7367), 29, 2011.

9. STEFFEN W., RICHARDSON K., ROCKSTRÖM J., CORNELL S.E., FETZER I., BENNETT E.M., et al. Planetary boundaries: guiding human development on a changing planet. Science, 347, 1259855, 2015.

10. GEORGE T.S., GILES C.D., MENEZES-BLACKBURN D., CONDRON L.M., GAMA-RODRIGUES A.C., JAISI D., et al. Organic phosphorus in the terrestrial environment: a perspective on the state of the art and future priorities. Plant Soil, 427, 191, 2017.

11. CHARLTON M.B., BOWES M.J., HUTCHINS M. G., ORR H.G., SOLEY R., DAVISON P. Mapping eutrophication risk from climate change: future phosphorus concentrations in English rivers. Science of the Total Environment, 613, 1510, 2018.

12. HANUŠIN J. Waters. Natural beauty in Slovakia, Dajama, 128, 2009.

13. VARGA P., LELKES G., FÖLDES C. The economic and social development of the village Č́íčov. 80, 2006.

14. GOVERNMENT REGULATION SR No. 269/2010 Z. z., laying down the requirements to achieve good water status.

15. BABOŠOVÁ M., NOSKOVIČ J., ČERYOVÁ T. Influence of natural and anthropogenic resources on water quality in the National Nature Reserve Čičov oxbow. Slovak University of Agriculture in Nitra, 88, 2018.

16. FUKSA J.K. Water quality in Czech streams in 2013. Water management, 66 (1), 7, 2016.

17. FREIRE R., BONIFÁCIO C.M., HERNANDES de FREITAS F., SCHNEIDER R.M. Nitrogen forms and total phosphorus in water courses: a study at Maringá stream, Paraná State. Acta Scientiarum Technology. 34 (4), 711, 2013.

18. PITTER P. Hydrochemie. Prague, 568, 2009.

19. PITTER P. Hydrochemie. Prague, 792, 2015.

20. HEJZLAR J., ZNACHOR P., SOBOLÍKOVÁ Z., ROHLÍK V. High eutrophication efficiency of phosphorus originating from wastewater in the Lipno reservoir. Water tanks. Water management conference, Brno, 2015.

21. WOJCIECHOWSKA E., NAWROT N., MATEJŁUKOWICZ K., GAJEWSKA M., OBARSKAPEMPKOWIAK H. Seasonal changes of the concentrations of mineral forms of nitrogen and phosphorus in watercourses in the agricultural catchment area (Bay of Puck, Baltic Sea, Poland). Water Supply, 19 (3), 986, 2019.

22. BABOŠOVÁ M., NOSKOVIČ J., IVANIČ PORHAJAŠOVÁ J. Evaluation of the concentration of inorganic forms of nitrogen and phosphorus under the forest ecosystem of the Čaradický stream. Journal of Central European Agriculture, 18 (4), 942, 2017.

23. BOROVSKÁ J. National Nature Reserve Parížske močiare as an Example of Wetlands. Životné prostredie, 47 (3), 152, 2013.

24. DĄBROWSKA J., BAWIEC A., PAWĘSKA K., KAMIŃSKA J., STODOLAK R., Assessing the Impact of Wastewater Effluent Diversion on Water Quality. Polish Journal of Environmental Studies, 26 (1), 9, 2017.

25. CHOW A.T., DAI J., CONNER W.H., HITCHCOCK D. Dissolved organic matter and nutrient Dynamics of a coastal freshwater forested wetland in Winyah Bay, South Carolina. Biochamistry, 112 (1), 571, 2012. 
